\title{
In silico comparative analysis of glycoside hydrolase (GH) family 10 endo-(1-4)-beta-xylanase genes from Eucalyptus grandis and Arabidopsis thaliana
}

\author{
Ritesh Mewalal", Desre Pinard, Eshchar Mizrachi, Alexander A Myburg \\ From IUFRO Tree Biotechnology Conference 2011: From Genomes to Integration and Delivery \\ Arraial d Ajuda, Bahia, Brazil. 26 June - 2 July 2011
}

\section{Background}

The hemicellulose xylan constitutes the major non-cellulosic component of plant secondary cell walls. It has been shown that xylan adsorbs to cellulose fibres and also covalently binds a carbon moiety of lignin [1,2]. Eucalyptus is an important hardwood tree genus used in the pulp and paper industry and has potential as biofuel feedstock. Xylan removal is expensive and uses environmentally harsh chemical treatments [3]. Previous studies have shown that endo-(1-4)- $\beta$-xylanase enzymes belonging to glycoside hydrolase $(\mathrm{GH})$ family 10 internally attacks the xylan backbone resulting in shorter xylo-saccharide chains [4]. The recently sequenced Eucalyptusgrandis genome (DOE-JGI, http://www.phytozome.net) provides a unique opportunity to analyze the native endo-(1-4)-beta-xylanase proteins involved in xylan modification in eucalypt fibre cell walls. Detailed knowledge of endogenous xylanolytic enzymes from Eucalyptus could facilitate the development of strategies to enhance the processing of woody biomass for cellulose and biofuel production. The aims of this study are to identify xylem secondary cell wall-related endo-(1-4)- $\beta$ xylanase genes in the $E$. grandis genome and to perform a comparative analysis of the Eucalyptus xylanasepeptide sequences with those of previously studied Arabidopsis orthologs to provide a framework for assigning function to the Eucalyptus enzymes.

\footnotetext{
* Correspondence: ritesh.mewalal@tuks.co.za Department of Genetics, Forestry and Agricultural Biotechnology Institute (FABI), University of Pretoria, Pretoria, 0002, South Africa Full list of author information is available at the end of the article
}

\section{Results}

Analysis of the E. grandis genome sequence on Phytozome v7.0 (http://www.phytozome.net) for putative endo-(1-4)- $\beta$-xylanase genes resulted in the identification of 18 putative GH10 family members. The expression profile of each family member was assessed (via mRNA-Seq analysis, http://eucspresso.bi.up.ac.za/) to identify members with putative roles in xylem secondary cell wall metabolism. Egrandis_v1_0.001952m (designated EgrXYN1) showed the highest xylem to phloem and xylem to leaf expression ratios of the expressed $E$. grandis GH10 genes [5]. BLAST analysis $(<1 \mathrm{e}-10)$ of the A. thaliana genome for putative orthologs to EgrXYN1 and co-phylogenetic analysis of all $18 \mathrm{E}$. grandis enzymes with the putative $A$. thaliana xylanases revealed that AtXYN1 (At1g58370) [4] was one of the closest putative orthologs to EgrXYN1 (Figure 1). Alignment of the predicted amino acid sequences of EgrXYN1 and AtXYN1 Jalview 2.6.1 revealed $68.76 \%$ identity between the two sequences.

In silico biochemical analysis predicted that EgrXYN1 has a molecular weight of $103 \mathrm{kDa}$ with a $\mathrm{pI}$ of 6.08 . This is very similar to AtXYN1 which is $102 \mathrm{kDa}$ with a pI of 6.1. The protein domain view in Phytozome (http://www.phytozome.net) revealed that EgrXYN1 contains three successive $\mathrm{N}$-terminal $\beta$-sandwich carbohydrate binding modules IV (at amino acid positions 53-185, 216-357 and 387-532) which were also observed in AtXYN1. A protein motif search (http://motif.genome.jp) revealed that EgrXYN1 also contained a conserved and identical C-terminal GH10 active site sequence "GLPIWFTELDV" at amino acid position 802812. Finally, de novo motif search of both AtXYN1 and 


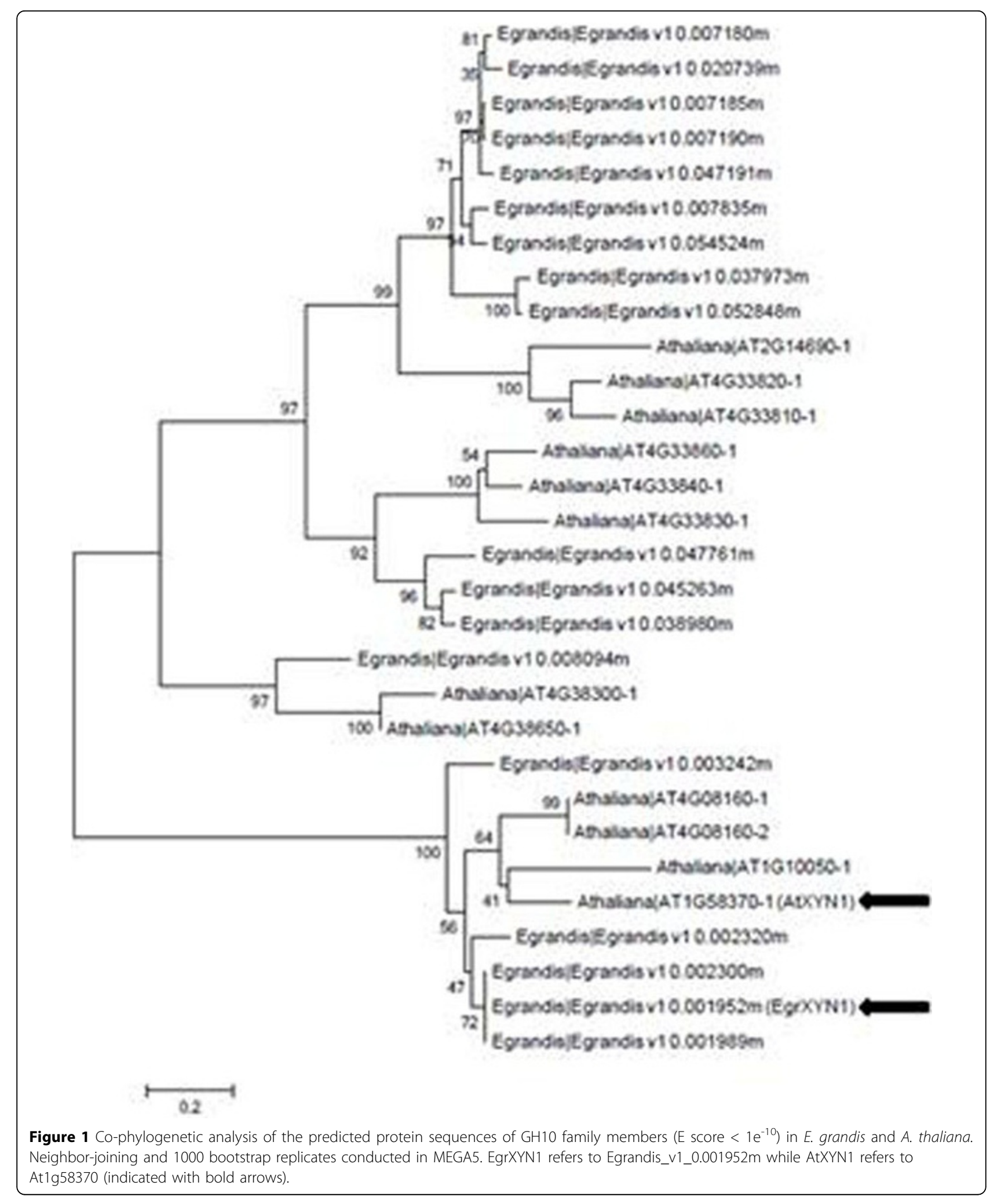




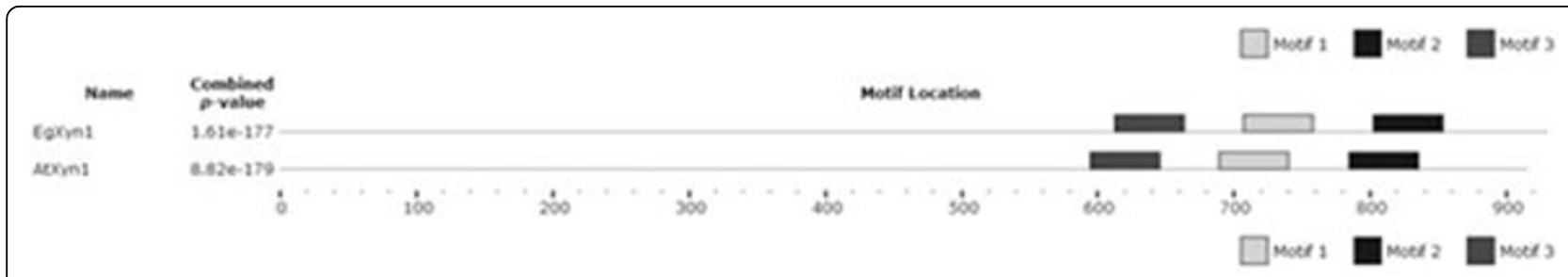

Figure 2 Mining of EgrXYN1 and AtXYN1 for novel motifs using MEME resulted in three additional motifs [6].

EgrXYN1 using MEME revealed the presence of three additional novel C-terminal motifs present within both enzymes (Figure 2).

\section{Conclusion}

The E. grandis genome contains 18 putative GH10 family members (at a BLAST threshold of $1 \mathrm{e}^{-10}$ ). One of these, EgrXYN1 is highly preferentially expressed in Eucalyptus xylem tissues and shows highest similarity to AtXYN1. The similarities between AtXYN1and EgrXYN1 suggest similar biochemical properties and biological functions. Previous studies showed that AtXYN1:: eGFP localized to the cell wall providing support for its function in cell wall modification. AtXYN1prom::GUS constructs expressed predominately in the vascular bundles suggesting that AtXYN1 (and therefore putatively EgrXYN1) is involved in secondary cell wall modification $[4,7]$. Future work will involve experimental validation of the biochemical properties and enzyme kinetics of EgrXYN1.

Published: 13 September 2011

\section{References}

1. Paananen A: Interaction between cellulose and xylan: An atomic force microscope and quartz crystal microbalance study. In In Hemicelluloses: Science and Technology. Volume 864. ACS Pub; 2004:269-291.

2. Barakat A, Winter H, Rondeau-Mouro C: Studies of xylan interactions and cross-linking to synthetic lignins formed by bulk and end-wise polymerization: a model study of lignin carbohydrate complex formation. Planta 2007, 226:226-267.

3. Battan B, Sharma J, Dhiman S: Enhanced production of cellulase-free thermostable xylanase by Bacillus pumilus ASH and its potential application in paper industry. Enz. Mic. Tech 2007, 41:733-739.

4. Suzuki M, Kato A, Nagata N: A xylanase, AtXyn1, is predominantly expressed in vascular bundles, and four putative xylanase genes were identified in the Arabidopsis thaliana genome. Plant Cell Phys 2002, 43:759-767.

5. Mizrachi E, Hefer C, Ranik M: De novo assembled expressed gene catalog of a fast-growing Eucalyptus tree produced by Illumina mRNA-Seq. BMC Gen 2010, 11:681-693.

6. Bailey T, Elkan C: Fitting a mixture model by expectation maximization to discover motifs in biopolymers. Proc. Int. Conf. Intell. Syst. Mol. Biol 1994, 2:28-36.

7. Oikawa A, Joshi $\mathrm{H}$, Rennie E: An integrative approach to the identification of Arabidopsis and rice genes involved in xylan and secondary wall development. Plos One 2010, 5:263-679.
doi:10.1186/1753-6561-5-S7-P168

Cite this article as: Mewalal et al:: In silico comparative analysis of glycoside hydrolase $(\mathrm{GH})$ family 10 endo-(1-4)-beta-xylanase genes from Eucalyptus grandis and Arabidopsis thaliana. BMC Proceedings 20115 (Suppl 7):P168.
Submit your next manuscript to BioMed Central and take full advantage of:

- Convenient online submission

- Thorough peer review

- No space constraints or color figure charges

- Immediate publication on acceptance

- Inclusion in PubMed, CAS, Scopus and Google Scholar

- Research which is freely available for redistribution

Submit your manuscript at www.biomedcentral.com/submit
C Biomed Central 